ISSN 2080-1653

DOI 10.24917/20801653.331.3

\author{
ANNA RUTKOWSKA-GURAK
}

Warsaw School of Economics, Poland

\title{
Location of Innovative Enterprises within Urban Technology Park in the Context of Economic Security
}

\begin{abstract}
Turbulent environment is causing increasing risk and uncertainty affecting the functioning of enterprises. Therefore, the need for strengthening their economic security is of basic importance to them. The goal of this paper is to present the understanding of economic security of enterprises from the perspective of enterprises situated in urban technology parks. The topic is relevant and has not been widely discussed yet, particularly within the analysed context of local economic security. To accomplish this goal, the research uses the case study method to analyse Lublin Science and Technology Park (LSTP) and its local environment of the city of Lublin. The study is based on standardised questionnaire directed to enterprises located in LSTP. Empirical studies referring to perception of economic security of enterprises are based on information gained from enterprises located in Lublin with the status of tenants of LPNT, which are used as a base for a case study. The study confirms that location in a technology park which is innovative city's space has a positive impact on economic security of enterprises. It also confirms the impact of the city on economic security of enterprises as city's space users. It is attributable both to new enterprises located in the technology park, as well as enterprises relocated there from other areas of the city.
\end{abstract}

Keywords: city of Lublin; economic security; economic security of enterprises; innovative enterprises; Lublin Science and Technology Park; urban technology park

Received: 15 September 2017

Accepted: 30 October 2018

\section{Suggested citation:}

Rutkowska-Gurak, A. (2019). Location of Innovative Enterprises within Urban Technology Park in the Context of Economic Security. Prace Komisji Geografii Przemysłu Polskiego Towarzystwa Geograficznego [Studies of the Industrial Geography Commission of the Polish Geographical Society], 33(1), 36-49. https://doi. org/10.24917/20801653.331.3

\section{INTRODUCTION}

Nowadays, business enterprises are functioning in a very highly turbulent world of changing environment. It results in an increasing risk and uncertainty associated with business activities. It also has a big impact on decisions related to locational choice. The pressure of change and uncertainty is high because of a continuing tendency to 
increasing instability and outbreak of crises that is partially due to the fact that ongoing turbulences largely have a structural and systemic base (Szymański, 2012). The uncertainty appears at all spatial levels including national, regional and local scale and it affects, although to various extent, activities of all types of entities. Functioning in the world where change is an attribute of political and socio-economic life entails the need for security, and economic security as its important component, and activities directed towards achieving it. This perspective embraces locational policy of an enterprise both at the initial stage, as well as at later stages of its functioning.

Enterprises are interested in finding locations which create more favourable conditions for functioning and development and thereby strengthen their economic security. Choosing location at local level they tend to concentrate in the areas and places characterised by advantages of location called urbanisation economies offered in cities and towns and particularly big cities. Urbanisation economies, defined as external economies accrue to enterprises because of labour and markets, package of infrastructure and ancillary activities typically associated with urban settings (Knox et al., 2007) underlying logic of local economic security (Kożuch, Sienkiewicz-Małyjurek, 2013) and influencing economic security of enterprises.

In the next stage of their location decision enterprises address locational approach to specific areas within cities which are the best to meet their expectations or just more suited to their particular needs, such as the need for economic security. Technology parks (TPs) ${ }^{1}$ are among such special urban spaces which offer specific and distinctive attributes of a place which respond to various expectations of enterprises comprising economic security. Technology parks are business environment institutions and as such institutions they contribute (with other tools of local, regional and national environment) to shaping and activating processes of innovation, because they create favourable conditions for setting up innovative businesses in cities (Zioło, 2012). TP can be considered as highly specialised type of innovative and high-tech business areas connecting science and business and acting as a medium facilitating innovative activity and high-tech industrial growth in terms of employment and production. They are treated as institutions catalysing local and regional economic and innovative growth and development.

It can be stated that technology parks as institutions dedicated purposely to innovative and high-tech growth firms contribute ex definitione to better functioning of firms (Rutkowska-Gurak, 2012) acting towards economic security of their tenants.

The goal of this paper is to present the understanding of economic security from the perspective of enterprises situated in urban technology parks. The term "economic security of enterprises" which is used as a basic category of analysis seems to be more appropriate to define the phenomenon than economic safety of enterprises which is also found in scientific literature. Economic security is more widely used as a term and it seems that it is better related to functioning of locally embedded entities at analysed micro level (see Kuciński, 2017). So far, the topic of economic security of an enterprise

\footnotetext{
${ }^{1}$ Science (and Technology) Park according to International Association of Science Parks (IASP) is defined as "organization managed by specialized professionals whose main aim is to increase the wealth of its community by promoting the culture of innovation and competitiveness of its associated businesses and knowledge-based institutions...it manages the flow of knowledge and technology amongst universities, R\&D institutions, companies and markets; facilitates the creation and growth of innovation-based companies through incubation and spin-off processes; and provides other value-added services together with high quality space and facilities".
} 
(from locational point of view) was not widely discussed in the world scientific literature except for some studies in Eastern European area of research where it has found bigger interest ${ }^{2}$.

The research serves to verify the hypothesis that location of enterprises in urban technology park contributes to their economic security. It answers the following questions: how economic security is understood, and what is the impact of urban technology park and city's environment as a place of location on economic security of enterprises located there.

The research is based on empirical studies carried out during the period from July to September 2016. To verify the hypothesis, the research adopts double perspective of analysis addressed to technology park and the city. The research uses case study method which is applied to analyse Lublin Science and Technology Park (LSTP) and its local environment of Lublin (city). The study is based on a standardised questionnaire directed to enterprises located in LSTP. Analytical studies referring to the perception of economic security of enterprises are based on information gained from 9 enterprises located in LPNT ( $1 / 5$ of total enterprises) in the city of Lublin which are used as a base for a case study.

\section{ECONOMIC SECURITY IN LITERATURE REVIEW}

In a basic sense, security is defined as a state without a threat (Łuszczyn, 2016). Basic and primary meaning comes from political and military understanding of this idea and thus originally and primarily it was attributable to functioning of a state and initially analysed at spatial level. Another basic usage refers to social group and individuals (Czaputowicz, 2012). Presently, it starts to be considered also on company level.

Typologies of security can be based on subject and object of security, environment, relation subject - environment or space-time (Łuszczyn, 2016). Various criteria which are used present different divisions and typologies of security (Czaputowicz, 2012; Gierszewski, 2013). Security is manifested in all areas of the entity's activity, and therefore its structure is in essence the same as the structure of entity's functioning, so different in context and form (Koziej, 2011). It results in multidimensional understanding of security which embraces, except for political and military meaning, also social security, public security, ecological security, informational security, as well as economic security. The idea of economic security is important both for the functioning of countries, regions, cities, as well as enterprises as space users.

Economic security is an important component of security because it endows a nation with appropriate characteristics of national economic environment which is in accordance with its interests (Neu, Wolf, 1994). In general, it can be defined as a state of certainty related to the functioning of economy and its development leading to the fulfilment of its economic interests (Jaźwiński, 2013). Economic security describes a relatively balanced endogenous and exogenous state of functioning of economy, in which imbalanced risk is maintained within defined and acceptable organisational and legal norms and principles of social co-existence (Raczkowski, 2012). Economic security in macroeconomic terms is seen through the perception of various economic indicators

${ }^{2}$ In the Polish scientific literature the topic is analysed by K. Kuciński (ed.) in Lokalizacyjne uwarunkowania bezpieczeństwa ekonomicznego przedsiębiorstw (2015); Lokalizacja ekonomicznie bezpieczna (2017); Komponenty Bezpieczeństwa ekonomicznego przedsiębiorstw (2018). 
like job stability, unemployment level and prospects for growth reflected in liquidity (Żukrowska, 2013) or through the perception of the potential of the economy and its resources such as geographical location, natural resources, industrial and agricultural potentials, the degree of socio-economic development or quality of public administration (Grigoreva, Garifova, 2015).

The search for security is directed towards development and competitiveness (Gilpin, Gilpin, 1987). It results in the maintenance of basic development indicators that make the economy of an organisation competitive or more competitive than other. Dynamism combined with innovativeness contributes to economic security of enterprises, which J. Pelkmans (1984: 56) summarises as follows: "dynamic firms could also be expected to be innovative..., which may be felt to strengthen the economic security of the firm".

Competitiveness and development dedicated to micro-level analysis in the context of economic security can be shortly defined as solvency of an entity such as an enterprise (or household) expressed in the capacity (ability) to settle liabilities (Stachowiak, 2012). K. Żukrowska (2013: 32) adopts a similar manner, defining economic security of enterprises as "the ability to balance the obligations in relation to the needs in the medium term". Indicating at the role of economic security at micro level Y. Shutyak et al. (2015) notices after Gichova the importance of the ability of an enterprise to predict threats in order to function effectively in the present and successfully develop in the future which involves economic security of enterprise as final goal of anti-crisis management.

Definitions of economic security of enterprises which are of descriptive character (discussed mainly in East European scientific literature) indicate various factors influencing economic security of enterprises confirming complex and multidimensional character of this concept. These factors distinguished by A. Ianioglo, T. Polajeva (2016) as threats to the economic security of enterprises are of external and internal character and can be divided into two groups comprising respectively: economic, political, legal, social, market, technological, natural factors as external threats and managerial, financial, labour, productive, marketing, legal, information and technological factors as internal threats. Definitions present selective or mix approach and underline not only (1) basic business perspective such as ability to accomplish financial goals but also (2) ability for (or to reach) stable development and (3) competitive advantage, (4) ability to use corporate resources in efficient way, (5) ability of prevention and protection from negative impact of threats and (6) harmonisation of enterprise economic interests with objects of external environment (Kozachenko et al., 2010; Ianioglo, Połajeva, 2016).

Positioning economic security reveals also context of relativity of economic security based on comparison of resources and potential related to different categories of entities such as states, cities, business areas including technology parks (Rutkowska-Gurak, 2015) and business entities.

The idea of economic security is important both for functioning of countries, regions and cities, as well as enterprises because business entities as space users and shapers contribute to the economic security of economic systems functioning on different spatial levels (Kożuch, Sienkiewicz-Małyjurek, 2013; Kurek et al., 2014; Shutyak et al., 2015). 


\section{ECONOMIC SECURITY OF ENTERPRISES LOCATED IN A TECHNOLOGY PARK}

Enterprises located in an innovative area created by Lublin Science and Technology Park in Lublin realise that economic security is shaped by various factors which represent different character (both exogenous and endogenous). Tenants of LSTP combine economic security with development, although predominantly perceived in the short run. As far as financial aspects of activity are concerned, firms emphasize the need of "financial liquidity" /"cash flow", "stability of income" and "tax stability", and also the need of "constant profits" or "certainty of continuing revenue streams". More than half of analysed firms sees the impact of exterior environment on their functioning which is understood as general conditions of stable economic environment and stable legal environment including legal order (obeying the rules) and stable tax environment "guaranteeing the firm the possibility of stable existence". Additional attention in the context of economic security is paid to the role of market which is analysed as "market certainty" and understood as the possibility of access to the market (at any time) using the ability of anticipating and minimising risk and readiness of quick adjustment to the changing market situation.

It is meaningful that economic security is also highlighted in the perspective of close neighbourhood of TP what shows the role of exterior environment understood not only as general legal and economic situation but associated directly and exclusively, in the case analysed, with sublocal environment. It was revealed by the response linking economic security with local business environment of LSTP perceived in the analysed case as "consulting services in management and economics". Although this point of view, as limited to very closed perspective of sublocal environment of the city (TP) stands out against other opinions, it highlights multidimensional advantages of location in technology park and its role in enhancing economic security of enterprises.

The approach presented above reveals "dual" character of economic security perception. All respondents notice the perspective related directly to endogenous factors exposing economics of their activity which is the only approach for some of them. Adopting this narrow approach, economic security of an enterprise can be defined as $a$ state in which financial situation of a firm is secure and guarantees in a foreseeable future continuation of its operations (in the place of its location). Using a broader approach (exposing both exogenous and endogenous factors) represented by fewer respondents but still majority of them, economic security of an enterprise can be interpreted as a state of general legal, macroeconomic and market environment of an enterprise that favours to accomplish its economic goals, thus guaranteeing the achievement of expected material benefits of stable existence and development (in the place of its location) (see also: Kuciński, 2017: 13).

\section{SUBLOCAL PERCEPTION (TP) OF ECONOMIC SECURITY OF ENTERPRISES LOCATED IN A TECHNOLOGY PARK}

Enterprises located in LSTP share the opinion that there is an impact of technology park on their economic security as the majority of them see the role of TP as an important factor affecting their economic security. All take into consideration a possible interdependence between this place of location and their economic security because none of the firms denies that such interdependence may exist. 
Enterprises located in TP find that this particular location in the city space brings certain benefits that influence their economic efficiency and affect their economic security. It is manifested through the impact on the basic performance indicators (half of the analysed companies point to the link between the factors distinguished as influencing economic security and the revenue/cost indicators).

They find low and preferential cost of renting of high standard office space as primary advantage of their location which has important cost-reduction effect on their business operations. They find location in TP as a good or the best location in the city. It is also confirmed by the fact that two surveyed firms relocated to the park from the city finding it more attractive than previous location and alternative city locations. Moreover, none of the surveyed firms is interested in changing location from LSTP to other areas of the city or region.

Firms share the opinion that the technology park offers successful interdisciplinary advice helpful both for start-ups using the space of Technology Incubator, as well as other tenants. The enterprises appreciate professional and multidimensional support from local experts. This support is very strongly stressed, so taking general view it is the advantage which is the most important. Tenants enumerate different activities undertaken by TP's staff. They are related to the area of law, economy, finance, and management. They appreciate the role of the park in the area of business' acceleration and supportive role of the management board of LSTP and specialised staff of its inno-brokers. It is worth to notice that received business support completely determined the approach to economic security of one of the incubated enterprises.

Tab. 1. Impact strength of attributes of Science and Technology Park in Lublin on economic security of enterprises

\begin{tabular}{|l|c|}
\hline \multicolumn{1}{|c|}{ Attributes of LSTP } & $\begin{array}{c}\text { Impact strength } \\
\text { (the number of indications) }\end{array}$ \\
\hline Preferential costs of renting & ++++ \\
\hline Location & ++ \\
\hline Activity of technology park in the area of acceleration & + \\
\hline Support & + \\
\hline Support (on the part of the chairman of the board of LSTP) & + \\
\hline Advice of experts and inno-brokers & + \\
\hline Legal assistance & + \\
\hline Business networking & + \\
\hline
\end{tabular}

Source: Own work based on opinions of surveyed tenants of LSTP

TP's role in business acceleration is exposed through participation in different programs (initiatives and participation) such as in the project of pre-incubation of startups in Technology Incubator called Project Create Lublin or management of regional platform supporting knowledge-based firms within the framework of acceleration program CONNECT Startup Platform. It functions under the Operational Programme Eastern Poland 2014-2020 the objective of which is to increase the number of innovative start-ups in Lubelskie region. The starting point of the program was very promising taking into account the interest of entrepreneurs shown in 330 new innovative ideas which were further evaluated. Prior to this program the LSTP participated in "Inno-broker project" which was directed toward commercialisation supporting activities in the 
area of innovation. LSTP was an institution which engaged as a pioneer in "creating" and training inno-brokers with the help of Lublin University of Life Science which is TP's shareholder. This innovative testing project called "New complex model of service of innovative business needs - INNO-BROKER" was carried out in the period 20132015 (Jakubiak, Małek, 2015: 238). Inno-brokers which were trained and employed by LSTP represent a new profession on Polish labour market. Inno-brokers activities are dedicated to innovative businesses by offering them comprehensive services including identification of research problems and seeking solutions to these problems. LSTP's inno-brokers staff actively and successfully participates in efficient organisation of the transfer of knowledge to the economy which is manifested in cooperation with LSNT tenants, city and region (Małek et al., 2015).

Successful support offered to tenants is also evidenced in good cooperation of enterprises with management staff of TP. Competencies of the Chairman of the Board, Tomasz Małecki evident among other in the field of acceleration and activation of innovative processes were also appreciated on regional market because he was chosen as one of top 10 managers of Lubelskie Region in 2015.

Another positive aspect of 'TP' influence is seen in the impact on forming and strengthening business contacts. TP's space does it in different ways due to infrastructure services and concentration of innovative businesses. Enterprises stress possibility of access to the four modern, well equipped conference and training rooms which are used by tenants as meeting places with clients. TP is helpful in initiating, forming, and strengthening relations and interactions with existing and potential clients outside TP, as well as tenants and park's supporting team. As a result tenants gain many and differentiated networking benefits.

Tab. 2. Impact of location in LSTP on economic security of enterprises

\begin{tabular}{|l|l|}
\hline \multicolumn{1}{|c|}{ Impact of location } & \multicolumn{1}{|c|}{ Character of location in TP } \\
\hline $\begin{array}{l}\text { Allows to cut costs, also there is a possibility to use } \\
\text { conference rooms for meetings with clients }\end{array}$ & First location \\
\hline Existing support from economic experts and inno-brokers & First location \\
\hline I feel that I have a support & First location \\
\hline $\begin{array}{l}\text { Attractive price for renting an office space and networking } \\
\text { benefits which have an impact on improving revenues and } \\
\text { lowering rental costs }\end{array}$ & Relocation \\
\hline Low cost of office space and substantive support & Relocation \\
\hline
\end{tabular}

Source: Own work based on opinions of surveyed tenants of LSTP

Positive aspects of location in TP are seen and emphasized by different groups of tenants taking into consideration their business life cycle, access to TP's infrastructure (such as Technology Incubator) and locational experience (TP's start-ups and relocated firms). However, the perception of relation to economic security is not unique in such a sense that $1 / 3$ firms although they notice importance or necessity of incubation on preferential treatment they do not relate it directly to their economic security. On the other hand all these firms confirm advantages of location and support of the park in the area of acceleration. They find their current location as the best possible (for their business life cycle) and one company has not denied that it could be the best possible. 
Analysis shows that both (two) relocated firms expressed high satisfaction with location, pointing out also the direct impact on their economic efficiency and economic security. They strongly underlined the linkage between location and economic security through the impact on lowering costs and increasing revenues. It was not only due to positive impact of attractive price for renting an office space for cost reduction but also due to the effect of "substantial support" offered in many forms by TP and positive impact of networking benefits stimulated directly and indirectly by TP.

Advantages of location in TP in the context of economic security have not been outweighed by disadvantages and barriers because no enterprise noticed any factors (barriers) affecting negatively their economic security in TP. Some of the firms (5 out of 9) indicated only at activities which they were expected to be delivered to help their better functioning. They underlined the need for organisation of more workshops (in the area of firm's management, management of modern technologies and accounting). They identified the need of utilisation of services offered by tenants and the need for more active support in this matter on the side of TP. They also expressed expectation toward more multidimensional support of inno-brokers related to gaining clients and the need for constant cooperation in this important area of firm's activity. It indicates that expectations of some tenants are related to the whole cycle of enterprise's functioning in a continuous period.

\section{URBAN CONTEXT OF ECONOMIC SECURITY}

Economic security of enterprises is shaped and reshaped also by close external environment of the city. It is characterised by the concentration of people as inhabitants or commuters and concentration of businesses, institutions, and supportive infrastructure. This sort of clustering is activity- and innovation driven which was already summarised by Marshall's notes about spirit of innovation accompanying agglomeration of economic activities (Berry, Conkling, Ray, 1997).

This urban context together with sublocal environment of technology park create specific conditions of local economic security and affect the functioning of enterprises located there. Enterprises situated in technology park in Lublin notice the impact of the city on their economic efficiency and economic security underlining its multidimensional character. It is evidenced by a set of 19 features describing urban secure environment which were chosen by surveyed enterprises out of a set of 21 proposed in a survey. It confirms the complexity of functioning of a big city, and such is Lublin with population number exceeding 300,000 .

Enterprises operating in the city of Lublin appreciate especially five features of the city with high influence on their economic security, grouped with regards to their importance (according to the number of indications made by surveyed firms). The city's images that contribute to perceived economic security of enterprises located in TP are the following: openness to changes, concentration of high-tech firms, developed innovative environment as the most important characteristics, and other important features like concentration of innovative firms, and pro-innovative and pro-entrepreneurial urban policy.

The next group of features of less importance underline the role of proper management of the city by exposing the role of appropriate development strategy and appropriate development strategy related to development of technology park. LSTP tenants 
appreciate highly developed entrepreneurial climate and student potentials like a big number of students as the most important feature of academic potential of a city, noticing also geographical location as more important than the size of the city. They outnumber also (however with smaller importance) other factors related to academicimage of a city, such as big number of universities. They stress the importance of quality of urban space depending on spatial order related to Local Spatial Development Plans, public security and the quality of life and see the impact of city' size (see also Rutkowska-Gurak, 2015).

The study reveals high compatibility of enterprises' expectations with Lublin Development Strategy 2013-2020. The strategy presents four strategic areas of city's development, i.e.: Openness, Friendliness, Entrepreneurship, and Academic Spirit (Janiszewska et al., 2014; Lublin Development Strategy 2013-2020). All four characteristics provided in the urban strategy are highlighted by surveyed LSTP's enterprises, however they put different emphasis on each of them. As the firms represent innovative and high-tech business users of the city's space, particular attention is given to openness, as well as innovation and entrepreneurship of the city. Academic spirit is highlighted particularly through the number of students perceived as potential human capital and labour pool treated as the catalyst for future growth, especially for high-tech firms and innovative firms. Reviewed LSTP's tenants are of this type, as they represent IT sector, biotechnology sector and research area. Friendliness is noticed and appreciated by tenants of LSTP with relation to good quality of life and public security.

Although Lublin Development Strategy does not formulate a direct relation to the development of LSTP, it has, however, an indirect connotation. It is reflected by photo image of LSTP as one of important city stakeholders which is associated with the vision and mission of the city (Lublin Development Strategy 2013-2020: 26).

Firms located in LSTP emphasize strong student and academic potential of the city, noticing also the advantages of local business environment institutions triggering innovative activity. Such an approach is supported by statistical image related to indicators of education positioning Lublin as a regional capital of knowledge and education which is illustrated, among other, by the number of students - students constitute about $20 \%$ of all inhabitants (Lublin. Potencjał edukacyjny miasta). Academic potential of Lublin is seen also in nationwide context, because it is ranked among the 8 largest Polish academic centres that educate about $40 \%$ of all student population in Poland (Harańczyk, 2008).

The case of Lublin confirms that firms recognise the importance of strategic and program documents defining directions of city's development and in this context the role of Lublin Development Strategy. One of firms indicated it as the only advantage of Lublin, not giving any week points. It positively highlights its formal and practical meaning.

Paradoxically part of advantages of Lublin are associated with weak economic standing on the map of Poland, expressing historically poorer economic development of Eastern Poland. And so, lower wages of employees characterising local labour market, in comparison to capitals of voivodeships in other regions, bring benefits for Lublin's firms by cutting costs of operations. In turn, weak competition and underdevelopment leaves more room for development and catching up process, thus creating easier entrance and more possibilities for innovative growth firms. Disadvantages of Lublin influencing economic security are related to poorer economic standing of the Eastern Part of Poland in comparison to other regions of the country. Dense and well- developed 
Fig. 1. Advantages and weak points of Lublin, influencing the economic security of entrepreneurs in comparison to other cities

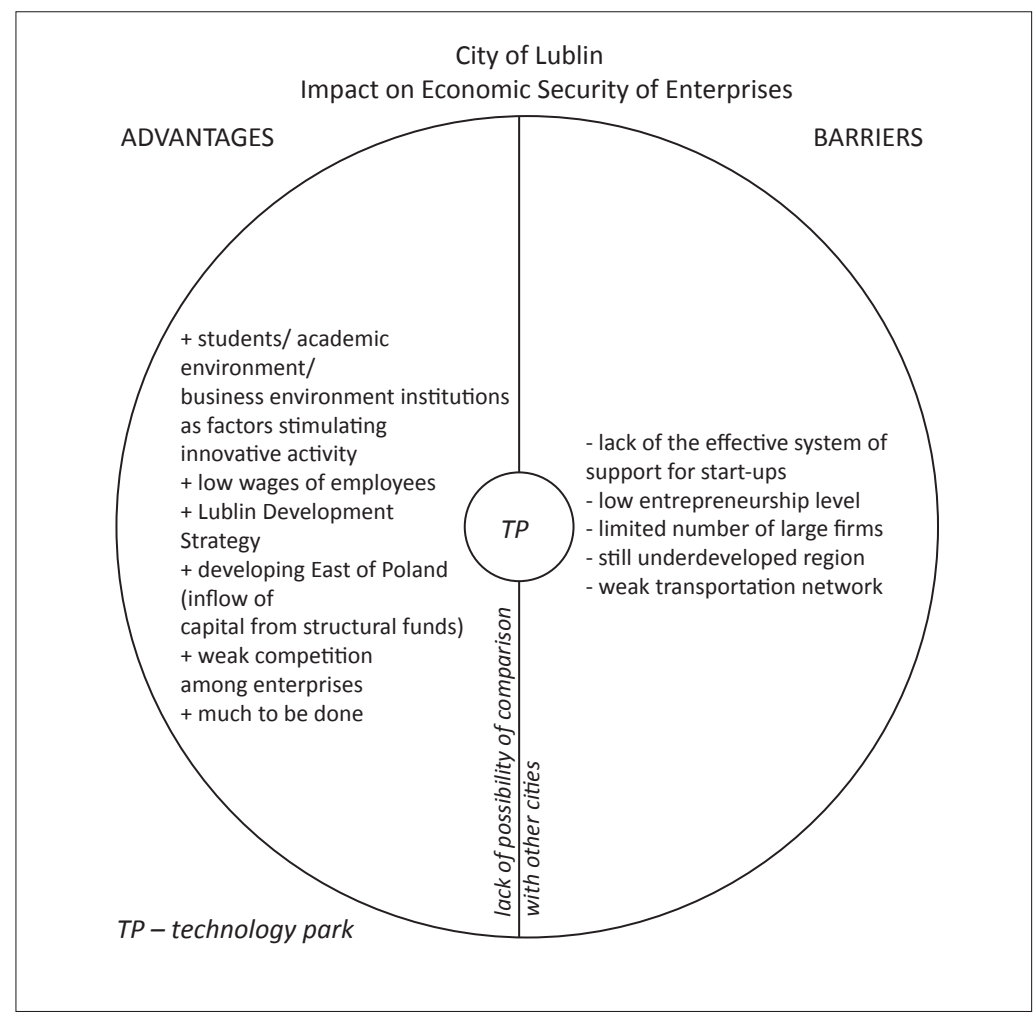

Source: Own work based on opinions of surveyed tenants of LSTP

local institutional environment is therefore contrasted with poor transport infrastructure constituting crucial barrier for attracting firms to the region and the city (Brdulak, Pawlak, 2017). Within this context, weak competition, although positive in the sense of leaving room for activity on local and regional market, is seen simultaneously as a disadvantage due to the low level of entrepreneurship and the lack of big firms serving as catalysts for multiplier entrepreneurship effect (on local and regional growth). Positive reception of the activities of Lublin authorities with regards to Lublin Development Strategy is contrasted with criticism of efficiency of tools implemented to support local start-ups such as Business Benefit card supportive impact which for some businesses is below expectations.

Different advantages and disadvantages which were enumerated show high relativity and differentiation of local approach of reviewed firms to economic security, associated with the domain of their innovative activity, length of life time and operational experience together with locational experience of the firm. One firm indicated directly the relativity of local impact on its economic security, admitting that it cannot compare possible impact of other city's location without locational experience in other city.

The impact of Lublin on the economic security of enterprises is perceived in different ways and to a various degree. Summing up the impact of Lublin on economic security, the majority of firms operating in Lublin assessed impact of the city positively 
as medium, with one (relocated) enterprise finding it as big and only two seeing it as week. Although perception was differentiated, all enterprises noticed a relation between their economic security and the city, which clearly confirms the impact of urban environment on the economic security of enterprises.

Tab. 3. The impact of Lublin on the economic safety of enterprises located in TP

\begin{tabular}{|c|c|c|c|c|}
\hline big & medium & weak & without & $\begin{array}{c}\text { not known } \\
\text { ("I don't know") }\end{array}$ \\
\hline+ & ++++++ & ++ & - & - \\
\hline
\end{tabular}

Source: Own work based on opinions of surveyed tenants of LSTP

Each firm saw different character of impact (various number and set of distinguished factors) with a maximum of 8 factors enumerated by the firm which saw an impact as the highest. Such an opinion was expressed by a relocated firm, being also the oldest in reviewed group (three years of market functioning) which creates the possibility of a wider perspective of assessment of city's impact. It reveals a double impact of the city and technology park on the economic security of enterprises.

\section{CONCLUSIONS}

The study shows that innovative enterprises, while defining the idea of economic security and considering factors affecting it, take into consideration the role of various factors of both external and internal character (compare Kuciński, 2018). The complexity of various factors of impact is seen in a multidimensional approach reflected in broad and narrow dimension. The emphasis is on short-term run business perspective. The security of enterprises is understood as the ability of stable functioning and development (legal and tax stability) largely in a foreseeable future in a place of location which enables the harmonisation of enterprises' interests with external environment (see Kozachenko et al., 2010; Ianioglo, Połajeva, 2016). Firms strongly focus on a short-term business perspective as this period has high risk regarding the survival of young innovative firms on the Polish market (it is the status of all surveyed firms).

Economic security of enterprises is understood both widely as general conditions of legislative, administrative and market nature, and also local conditions of close neighbourhood inherent to the city and its specific locational areas like LSTP representing urban sublocal environment supporting growth and development of high-tech innovative firms in Lublin. As a result, surveyed firms situated in LSTP represent "double local logics of location" which shapes their current perception of economic security.

The analysis shows that technology parks have a real influence on shaping the economic security of businesses, especially small and innovative companies for which professional incubation (location in Technology Incubator) is extremely important for their early stage of development. It enhances their economic interests and contributes to local economic security. The technology park is perceived also as a space considerably supporting the functioning of relocated high-tech firms from other areas of the city by supporting their operational activities in a direct (financial beneficiaries) and an indirect way (ex. business network, workshops), and thus successfully influencing economic security. Technology parks play an important role in supporting innovative firm's growth and strengthening the security of their business activities. Tenants 
expect support at various stages of their functioning. Activity of TP's staff and multidimensional support of the technology park is highly appreciated, particularly in the area of acceleration of innovative business development.

Tenants of LSTP also confirm supportive and multidimensional impact of the city of Lublin on economic security. Firms find such features of the city as openness to changes, innovative environment concentrating innovative and high-tech firms supported by pro-innovative and pro-entrepreneurial urban policy as the most fundamental for building their economic security as business city space users. Assessing the impact of the city in the context of relativity of economic security (in comparison to other cities) they highlight traditional, historical assets such as student and academic potential of the city, but appreciate also the managerial skills of Lublin authorities and the role of strategic documents such as Lublin Development Strategy. It confirms the importance of the management of a city (Kuciński, 2011). Some of the enterprises point out the disadvantages of Lublin, which however have various connotation because they are treated both as a barrier for growth and an opportunity/stimulus for development. Firms indicate at universal features of well-functioning city with a good business, innovative and entrepreneurial climate and indicate specific features assessed through the view of Lublin associated, among other, with the geographical position of Lublin.

The research highlights new aspect of the role of technology park as a place of location and confirms its positive impact on economic security. It emphasizes multidimensional advantages of technology park's location and its role for creating safe space of location from the economic point of view. LSTP as a space contributing to economic security of enterprises has a favourable impact on the creation of innovative environment in the city, contributing to strengthening local economic security which in turn shapes the economic security of urban space users, including tenants of TP.

The study contributes to the research area for further in-depth studies focused on understanding the idea of economic security of enterprises located in TP and factors enhancing/diminishing it. It involves the approach related to internal factors such as the policy of enterprises with focus on locational choice (internationalisation of activity) or attributes of present location like local cooperation and approach related to external factors inherent for a given TP and their urban environment analysed within the framework of comparative studies.

\section{References}

Berry, B.J.L., Conkling, E.C., Ray, D.M. (1997). The global economy in transition. Upper Saddle River, NJ: Prentice Hall.

Brdulak, J., Pawlak, P. (2017). Przedsiębiorstwo w rachunku ekonomicznym skutków inwestycji drogowych [Enterprise in the Economic Account of the Effects of the Investments in Road Infrastructure]. Kwartalnik Nauk o Przedsiębiorstwie, 42(1), 47-61.

Czaputowicz, J. (2012). Bezpieczeństwo międzynarodowe. Współczesne koncepcje [International Security. Contemporary Concepts]. Warszawa: Wydawnictwo Naukowe PWN.

Gierszewski, J. (2013). Bezpieczeństwo wewnętrzne [Internal Security]. Warszawa: Difin.

Gilpin, R., Gilpin, J.M. (1987). The Political Economy of International Relations. Princetion: Princeton University Press.

Grigoreva, E., Garifova, L. (2015). The Economic Security of the State: The Institutional Aspect, International Conference on Applied Economics, 2-4 July, Kazan, Russia. In: Procedia Economics and Finance, 24, 266-273. Retrieved from http://creativecommons.org/licenses/by-nc-nd/4.0/ 
Harańczyk, A. (2008). Potencjał rozwojowy szkół wyższych Małopolski [Potential for Growth in Universities of Malopolska]. Przedsiębiorczość-Edukacja [Entrepreneurship-Education], 4, 37-59.

Ianioglo, A., Połajeva, T. (2016, 12-13 May). Origin and Definition of the Category of Economic Security of Enterprise, $9^{\text {th }}$ International Scientific Conference "Business and Management. Vilnius. Retrieved from http://bm.vgtu.lt/index.php/verslas/2016/paper/viewFile/47/47

Jakubiak, M., Małek, A. (2015). Studium procesu rekrutacji na stanowisko inno-brokerów [The Study of the Recruitment Process for the Positions of Inno-brokers]. Ekonomia, Zeszyty Naukowe WSEI, 10(1), 153-168.

Janiszewska, O., Habza, E., Czerwiński, K., Wiśniewska, K. (2014). Strategia Lublin 2020 oczami studentów [The Lublin 2020 Strategy in the Eyes of the Students]. In: M. Sagan, K. Żuk (eds.). Lublin 2020. Cztery oblicza przyszłości miasta [Four Faces of the Future of the City]. Lublin: Wydawnictwo UMCS, 491-508.

Jaźwiński, I. (2013). Bezpieczeństwo ekonomiczne Polski. Strategiczne aspekty i wyzwania [Poland's Economic Security. Strategic Aspects and Challenges]. In: S. Wojciechowski, A. Wejkszner. Kluczowe determinanty bezpieczeństwa Polski na poczatku XXI wieku [The Key Determinants of Poland's Security at the Beginning of the 21st Century]. Warszawa: Difin, 319.

Knox, P.L., Marston, S.A., Nash, A.E. (2007). Human Geography places and regions in global Context. Toronto: Pearson Education.

Kozachenko, G., Lyashenko, O., Bezbozhnyy, V. (2010). Enterprise Economic Security Management Conception. Retrieved from http://www.pan-ol.lublin.pl/wydawnictwa/ TMot10a/Kozachenko.pdf

Koziej, S. (2011). Bezpieczeństwo: istota, podstawowe kategorie i historyczna ewolucja [Security: the Core, Basic Categories and Historical Evolution]. Bezpieczeństwo Narodowe, 18, 20.

Kożuch, B., Sienkiewicz-Małyjurek, K. (2013). Collaborative networks as a basis for internal economic security in sustainable local governance. The case of Poland. In: K. Raczkowski, F. Schneider (eds.). The Economic Security of Business Transactions Management in Business. Oxford: Chartridge Books Oxford.

Kuciński, K. (ed.) (2011). Miasto jako analog przedsiębiorstwa [City as analog of enterprise]. Warszawa: Szkoła Główna Handlowa.

Kuciński, K. (ed.) (2017). Lokalizacja ekonomicznie bezpieczna [Economic Security of Location]. Warszawa: CeDeWu.

Kuciński, K. (ed.) (2018). Komponenty bezpieczeństwa ekonomicznego przedsiębiorstw. [Components of Economic Security of Enterprises]. Warszawa: CeDeWu.

Kurek, S.T., Pietrzyk, K., Płaczek, J. (2014). Potrzeba opracowania zintegrowanej strategii kształtowania bezpieczeństwa ekonomicznego Polski [The need to develop an integrated strategy for shaping Poland's economic security]. In: Bezpieczeństwo ekonomiczne obrotu gospodarczego [Economic security of economic turnover]. Warszawa: Wolters Kluwer.

Lublin Development Strategy 2013-2020 (2013). Lublin: Department of Strategy and Investor Services.

Lublin. Potencjał edukacyjny miasta [Lublin. Educational Potential of the City]. Retrieved from https:lublin.eu/biznes-i-nauka/nauka/potencjal-edukacyjny-miasta

Łuszczyn, W. (2016). Bezpieczeństwo państwa a rozwój społeczno-gospodarczy [Safety of the State and Socioeconomic Growth]. Warszawa: CeDeWu.

Małecki, T. (2016, 13 May). Mamy młodych ludzi głodnych sukcesu [We Have Young People Hungry for Success]. Rzeczpospolita.

Małek, A., Dąbrowska, I., Ratajczyk, M. (2015). Poprawa współpracy biznesu z nauką w wyniku działań innobrokerów [The Improvement in Cooperation of Business and Science As a Result of the Inno-brokers' Activities]. Gorzów Wielkopolski, 3. After: D. Kowalczyk, A. Miłek. Model współpracy uczelni technicznej z parkiem naukowo-technologicznym [Model of the Cooperation Between a Technical University and a Science and Technology Park]. Lublin: Instytut Badawczo-Rozwojowy LPNT.

Neu, R.C., Wolf, Ch. (1994). The Economic Dimensions of National Security. Rand Corporation. Retrieved from http://www.rand.org/pubs/monograph-reports/MR466.html

Pelkmans, J. (1984). Market Integration in the European Community. The Hague: Nijhoff. 
Raczkowski, K. (2012). Bezpieczeństwo ekonomiczne. Wyzwania dla zarzadzania państwem. [Economic safety. Challenges for the Governance of the State]. Warszawa: Wolters Kluwer, 81.

Rutkowska-Gurak, A. (2012). Contemporary Changes in City's Growth (Glocalization and Technological Parks in Poland). ECON, Journal of Economics, Management and Business, Technical University of Ostrava, 22(2), 129-138.

Rutkowska-Gurak, A. (2015). Lokalne determinanty bezpieczeństwa ekonomicznego [Local determinants of economic security]. In: K. Kuciński (ed.). Lokalizacyjne uwarunkowania bezpieczeństwa ekonomicznego przedsiębiorstw [Local determinants of economic security of enterprises]. Warszawa: CeDeWu, 102-108.

Science Park. Retrieved from https://www.iasp.ws/Our-industry/Definitions

Shutyak, Y., Danylenko, O., von Caillie, D. (2015). The Concept of Economic Security of Enterprise in Ukrainian Economic Thoughts in ZN WSH. Zarzq̨dzanie, 4, 27-45. Retrieved from http:// www.humanitas.edu.pl/resources/upload/dokumenty/Wydawnictwo/Zarzadzanie_zeszyt/Zarz\%204_2015\%20podzielone/Shutyak\%20Danylenko\%20Caillie.pdf

Stachowiak, Z. (2012). Teoria i praktyka mechanizmu bezpieczeństwa ekonomicznego państwa: ujęcie instytucjonalne [Theory and Practice of the Mechanism of the State's Economic Security: Institutional Approach]. Warszawa: Wydawnictwo Akademii Obrony Narodowej.

Szymański, W. (2012, 29 March). Niepewność i niestabilność w gospodarce - wnioski z debaty „Czwartki u Ekonomistów” [Uncertainty and Instability in Economy - Conclusions from the Debate 'Thursdays with Economists']. Retrieved from http://www.pte.pl

Zioło, Z. (2012). Miejsce innowacyjności w kształtowaniu procesów rozwoju gospodarczego układów przestrzennych [The Role of Innovativeness in Creating the Processes of the Economic Development of Spatial Systems]. Prace Komisji Geografii Przemysłu Polskiego Towarzystwa Geograficznego, 20, 9-32.

Żukrowska, K. (2013). Ekonomia jako sfera bezpieczeństwa państwa [Economy as a Sphere of State Security]. In: K. Raczkowski, K. Żukrowska, M. Żuber (eds.). Interdyscyplinarność nauk o bezpieczeństwie [Interdisciplinarity of the Security Studies]. Warszawa: Difin.

\section{Acknowledgement}

The paper is based on the results of a statutory research conducted under the supervision of K. Kuciński, Warsaw School of Economics, 2016.

Anna Rutkowska-Gurak, PhD in economics from Warsaw School of Economics. Research area: economic geography with focus on local development, involving topics such as changes in growth of the cities, innovation and innovative city's activities, conditions of city's growth, development of innovative spaces and technology parks, location determinants of industry and innovative activities.

ORCID: 0000-0002-6498-9503

Address:

Warsaw School of Economics

Collegium of Business Administration

Department of Economic Geography

al. Niepodległości 162, 05-806 Warszawa, Poland

e-mail: agurak@sgh.waw.pl 